\title{
Adult Traumatic Atlantoaxial Rotatory Fixation: A Case Report
}

\author{
Zaw Min Han, ${ }^{1,2}$ Nobuto Nagao, ${ }^{3}$ Toshihiko Sakakibara, ${ }^{1}$ Koji Akeda, ${ }^{3}$ Takao Matsubara, ${ }^{3}$ \\ Akihiro Sudo, ${ }^{3}$ and Yuichi Kasai ${ }^{1}$ \\ ${ }^{1}$ Department of Spinal Surgery and Medical Engineering, Mie University Graduate School of Medicine, 2-174 Edobashi, \\ Tsu, Mie 514-8507, Japan \\ ${ }^{2}$ Department of Orthopaedic Surgery, University of Medicine, Mandalay, Myanmar \\ ${ }^{3}$ Department of Orthopaedic Surgery, Mie University Graduate School of Medicine, Japan
}

Correspondence should be addressed to Yuichi Kasai; ykasai@clin.medic.mie-u.ac.jp

Received 26 December 2013; Accepted 28 January 2014; Published 4 March 2014

Academic Editors: J. T. Hong, J. Mayr, A. F. Ozer, S. A. Papadakis, and S. Vanni

Copyright (c) 2014 Zaw Min Han et al. This is an open access article distributed under the Creative Commons Attribution License, which permits unrestricted use, distribution, and reproduction in any medium, provided the original work is properly cited.

We presented a very rare case of adult Fielding type I atlantoaxial rotatory fixation (AARF). We performed awake manual reduction of the dislocation without need for anesthesia, achieving excellent outcomes, and no previous reports have described awake reduction without the need for anesthesia. AARF in this case was attributed to excessive extension and rotation forces applied to the cervical spine. For the management of adult Fielding type I AARF, early diagnosis and early reduction may lead to excellent outcomes.

\section{Introduction}

We treated a very rare adult traumatic atlantoaxial rotatory fixation (AARF) with manual reduction while patient was awake, obtaining excellent outcomes. This case is reported together with a discussion of characteristics in adult cases.

\section{Case Report}

The patient was a 22-year-old man. While driving, he steered in the wrong direction at an intersection and collided with an oncoming car. After complaining of intense cervical pain, he was brought by ambulance to our emergency outpatient unit. He had no previous history of note.

On initial consultation, the patient could not move his head at all from its position facing to the right (Figure 1(a)). He had clear consciousness and no motor paralysis or sensory disturbance. A lacerated wound (Figure 1(b)), about $1 \mathrm{~cm}$ in length, was observed over the right inferior mandible. Computed tomography (Figure 2) revealed that the atlas was rotated to the right centering on the dens of the axis. However, no findings suggested congenital dysplasia, and no fractures such as the articular process were observed. Based on a threedimensional CT (Figure 3), we diagnosed AARF of Fielding classification type I [1] without a protruding eccentric jaw position.
Treatment comprised manual reduction while patient was awake about 2 hours after injury. At first, we held the mandible, providing traction in the cephalic direction, confirming that the patient did not develop pain or palsy in the upper extremities, and rotated it slowly to the left to obtain a feeling of reduction. Immediately after reduction, cervical pain was alleviated and no neurological complications were observed.

MRI after reduction indicated no major soft tissue damages, and CT after reduction (Figure 4) showed that the dislocation had been reduced, so fixation with a Philadelphia collar was performed. Radiography at 1 month after injury showed no intervertebral instability between $\mathrm{C} 1$ and $\mathrm{C} 2$, and the collar was removed at that time based on the strong request of the patient. CT at 1 year after injury showed no redislocation, and the patient had no cervical pain and was progressing satisfactorily.

\section{Discussion}

AARF is defined as torticollis caused by atlantoaxial dislocation or subluxation. Causes may include damage to soft tissues such as the articular capsule, transverse ligament, or alar ligaments between $\mathrm{C} 1$ and $\mathrm{C} 2$ or secondary contracture of the articular capsule or ligament tissues between $\mathrm{C} 1$ and $\mathrm{C} 2$ 


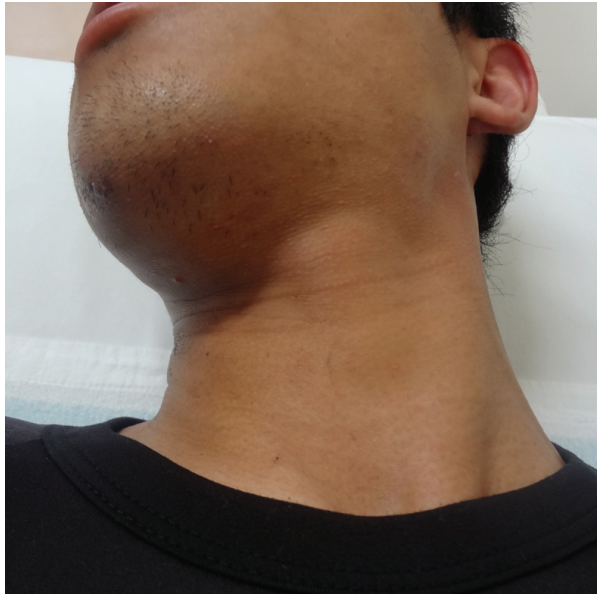

(a)

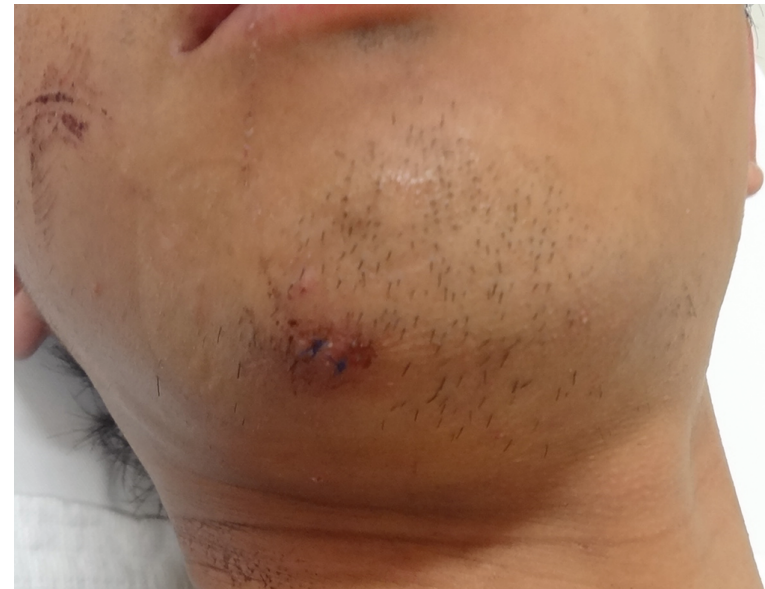

(b)

FIGURE 1: The patient could not move his head at all from its position facing to the right (a). A lacerated wound over the right inferior mandible (b).

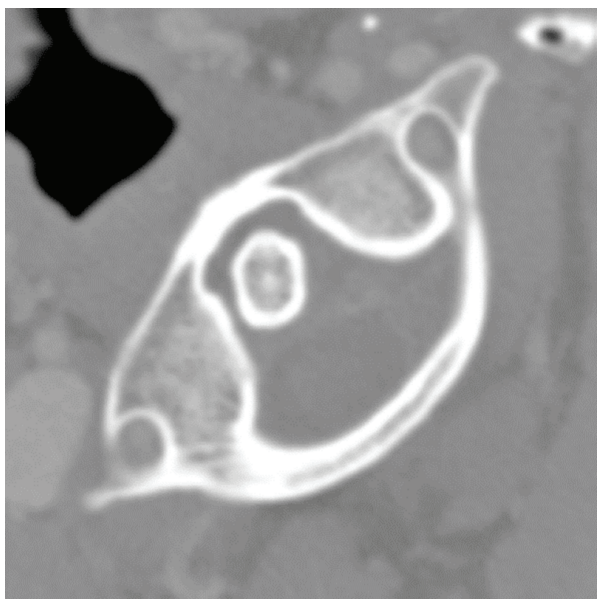

(a)

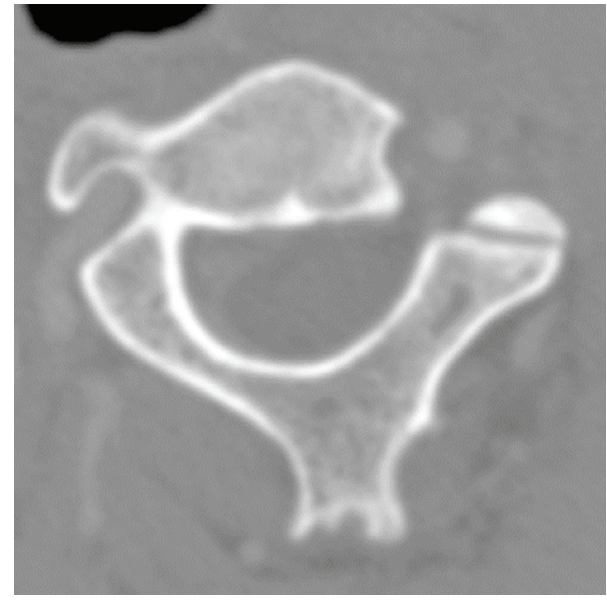

(b)

FIGURE 2: Computed tomography revealed that the atlas was rotated to the right centering on the dens of the axis. (a) Axial view of atlas and (b) axial view of axis.

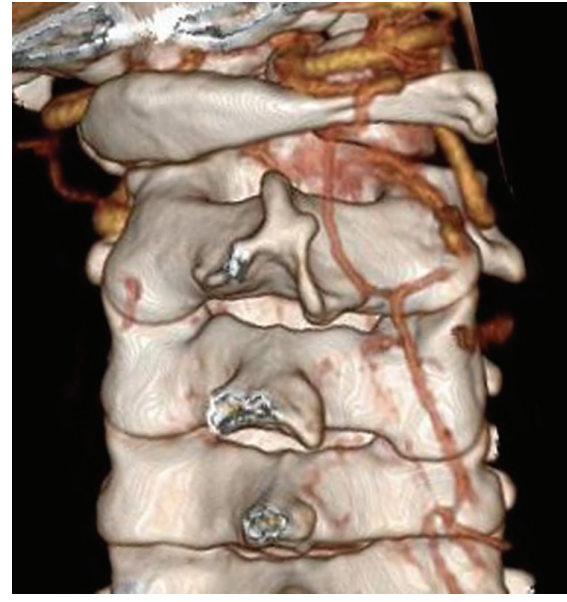

(a)

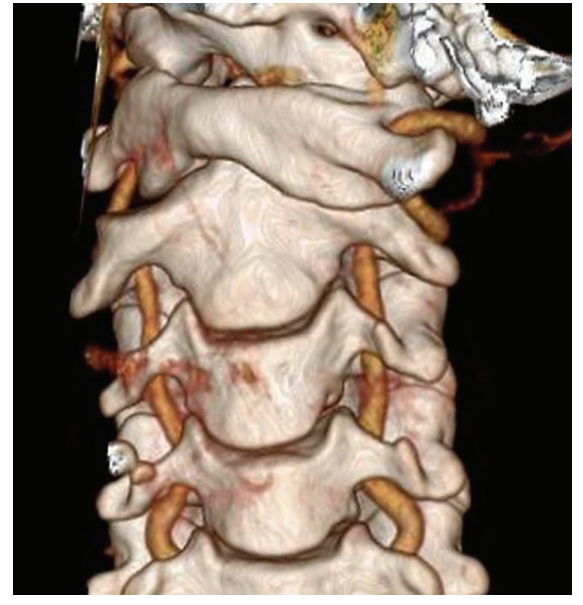

(b)

Figure 3: The three-dimensional CT showed atlantoaxial rotatory fixation of Fielding classification type I. (a) Posterior view and (b) anterior view. 


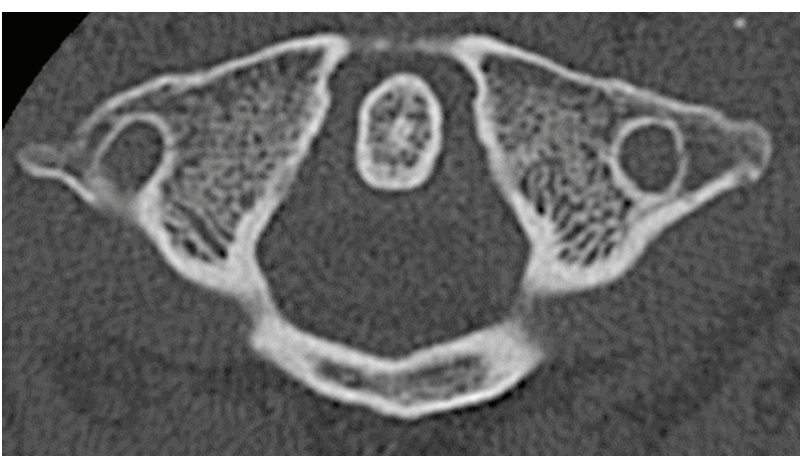

(a)

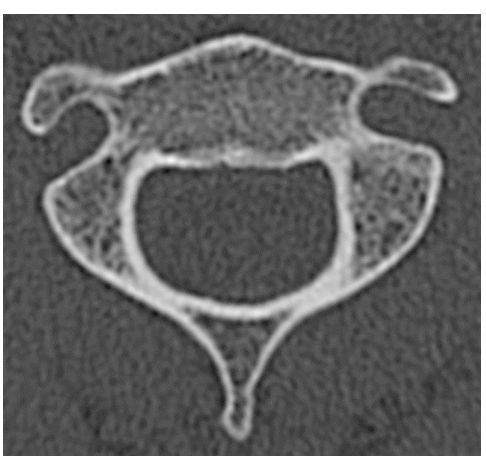

(b)

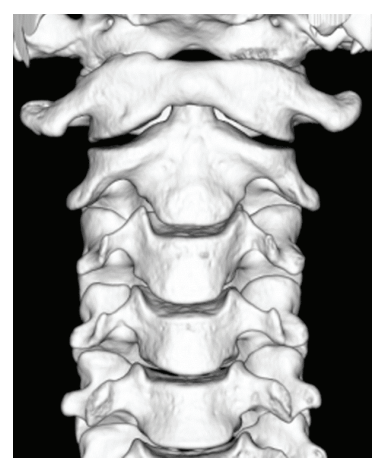

(c)

Figure 4: CT after reduction of atlantoaxial rotatory fixation. (a) Axial view of atlas, (b) axial view of axis, and (c) anterior view of threedimensional CT.

TABLE 1: Reported cases with adult atlantoaxial rotatory fixation in the literature.

\begin{tabular}{|c|c|c|c|c|c|c|c|}
\hline Author & $\begin{array}{l}\text { Age and } \\
\text { sex }\end{array}$ & Mechanism & $\begin{array}{l}\text { Fielding } \\
\text { type }\end{array}$ & Associated injuries & $\begin{array}{c}\text { Duration to } \\
\text { diagnosis }\end{array}$ & $\begin{array}{l}\text { Reduction method } \\
\text { and treatment }\end{array}$ & Results \\
\hline $\begin{array}{l}\text { Castel et al., } \\
2001[4]\end{array}$ & $41 \mathrm{M}$ & Rugby injury & I & $(-)$ & 1 month & $\begin{array}{l}\text { Reduction and } \\
\text { Minerva jacket }\end{array}$ & Good \\
\hline $\begin{array}{l}\text { Fuentes et al., } \\
2001[5]\end{array}$ & $24 \mathrm{M}$ & Suicidal jump & IV & $\begin{array}{l}\text { Initial odontoid } \\
\text { fracture only }\end{array}$ & 1 month & C1-C2 fusion & Unknown \\
\hline $\begin{array}{l}\text { Kim et al., } 2007 \\
{[8]}\end{array}$ & $34 \mathrm{M}$ & $\begin{array}{l}\text { Fall down from high } \\
\text { place }\end{array}$ & II & $\begin{array}{l}\text { Lt superior facet } \\
\text { fracture of } \mathrm{C} 2\end{array}$ & 1 day & $\mathrm{C} 1-\mathrm{C} 2$ fusion & Good \\
\hline \multirow{3}{*}{$\begin{array}{l}\text { Sinigaglia et al., } \\
2008 \text { [11] }\end{array}$} & $26 \mathrm{~F}$ & Road traffic accident & I & $(-)$ & 45 days & $\begin{array}{l}\text { Reduction and } \\
\text { halo vest }\end{array}$ & $\begin{array}{c}\text { Fair; because of } \\
\text { cervical stiffness } \\
\text { and headache }\end{array}$ \\
\hline & $21 \mathrm{~F}$ & Road traffic accident & I & $(-)$ & 1 day & $\begin{array}{l}\text { Reduction and } \\
\text { halo vest }\end{array}$ & Good \\
\hline & $29 \mathrm{M}$ & Road traffic accident & I & $(-)$ & 1 day & $\begin{array}{l}\text { Reduction and } \\
\text { rigid collar }\end{array}$ & Good \\
\hline $\begin{array}{l}\text { Wang et al., } \\
2008[14]\end{array}$ & $44 \mathrm{~F}$ & Not described & I & $(-)$ & 6 months & $\begin{array}{l}\text { Immobilization } \\
\text { with halo vest }\end{array}$ & $\begin{array}{c}\text { Poor; because of } \\
\text { bilateral hand } \\
\text { numbness }\end{array}$ \\
\hline $\begin{array}{l}\text { Goel et al., } 2010 \\
{[6]}\end{array}$ & $28 \mathrm{M}$ & $\begin{array}{l}\text { Fall down from high } \\
\text { place }\end{array}$ & $\begin{array}{c}\text { Not } \\
\text { described } \\
\end{array}$ & Odontoid fracture & 1 day & $\begin{array}{c}\text { Intraoperative facet } \\
\text { manipulation }\end{array}$ & Good \\
\hline $\begin{array}{l}\text { Singh et al., } \\
2009[10] \\
\end{array}$ & $25 \mathrm{~F}$ & Road traffic accident & I & $(-)$ & 0 day & $\begin{array}{c}\text { Skull traction and } \\
\text { halo brace }\end{array}$ & Good \\
\hline $\begin{array}{l}\text { Jeon et al., } 2009 \\
\text { [7] }\end{array}$ & $25 \mathrm{~F}$ & Road traffic accident & I & $\begin{array}{c}\text { Thoracic fractures, } \\
\text { alar ligament } \\
\text { injury }\end{array}$ & 5 days & $\begin{array}{c}\text { Immobilization } \\
\text { with Philadelphia } \\
\text { brace } \\
\end{array}$ & Good \\
\hline $\begin{array}{l}\text { Stenson, } 2011 \\
{[12]}\end{array}$ & $31 \mathrm{~F}$ & Falling backward & I & $(-)$ & 0 day & $\begin{array}{l}\text { Immobilization } \\
\text { with hard collar }\end{array}$ & Good \\
\hline $\begin{array}{l}\text { Marti et al., } 2011 \\
{[9]}\end{array}$ & $24 \mathrm{~F}$ & $\begin{array}{c}\text { Stretching neck } \\
\text { herself }\end{array}$ & I & $(-)$ & 1 day & $\begin{array}{c}\text { Reduction and } \\
\text { halo vest }\end{array}$ & Good \\
\hline \multirow{2}{*}{$\begin{array}{l}\text { Venkatesan et } \\
\text { al., } 2012[13]\end{array}$} & $20 \mathrm{~F}$ & Road traffic accident & I & $(-)$ & 0 day & $\begin{array}{l}\text { Skull traction and } \\
\text { hard collar }\end{array}$ & $\begin{array}{c}\text { Fair; because of } \\
\text { occipital pain }\end{array}$ \\
\hline & $52 \mathrm{~F}$ & Road traffic accident & I & $(-)$ & 0 day & $\begin{array}{l}\text { Halo traction and } \\
\text { hard collar }\end{array}$ & $\begin{array}{c}\text { Fair; because of } \\
\text { occipital pain }\end{array}$ \\
\hline
\end{tabular}

facet. This pathology is reported to occur frequently in children, triggered by slight trauma or upper respiratory infection in many cases [2]. The reasons for this predominance in children include (1) the relatively large size of the head in proportion to the rest of the body; (2) insufficient development of the muscular tissues around the neck; (3) increased elasticity of the C1-C2 joint capsule and large rotation angle; and (4) the horizontal configuration of articular facets [3].

Traumatic adult AARF as in the present case is reported very rarely, with only 14 cases identified in the literature since 2000 [4-14]. These reports are summarized in Table 1 and involved 5 men and 9 women between 20 and 52 years old 
(mean age, 30.3 years). AARF is frequently caused by highenergy trauma, such as that sustained in traffic accidents or falls. Since it is caused by high-energy trauma, patients often present with complicated damage such as articular cartilage lesions, articular process fractures, or spinal cord lesions $[5,15]$. As for the mechanism of onset in our patient, since he was involved in a head-on collision while driving and sustained a lacerated wound in the right inferior mandible, he presumably hit the right inferior mandible on the steering wheel, at which time excessive extension and rotation forces were applied to the cervical spine, resulting in rupture of articular capsule of $\mathrm{C} 1-\mathrm{C} 2$, leading to atlantoaxial rotatory fixation. The clinical findings showed typical torticollis after trauma and no features of neurological deficit.

In our review of 14 cases, 11 patients showed Fielding type I AARF and were treated with traction, manual reduction, or immobilization by cervical collar or halo vest, while the other 3 patients underwent surgery $[5,6,8]$. Most patients with Fielding type I undergo reduction using the traction method and immobilization with either a halo vest or different types of collars. Venkatesan et al. [13] reported 2 cases of AARF and commented that early recognition of atlantoaxial rotatory subluxation or dislocation is essential to successfully achieve closed reduction. Weißkopf et al. [16] pointed out that the success rate of conservative treatment decreases in proportion to the length of the dislocation treatment interval. Surgical stabilization is advised for cases of AARF showing spinal instability, neurological deficit, delayed diagnosis, failed reduction, and/or recurrent dislocation $[1,5,6,14]$.

Our patient presented with a very acute case of Fielding type I AARF with neither neurological symptoms nor complicating injuries such as bone fractures. We therefore performed manual reduction with the patient awake, and cervical pain was alleviated immediately after reduction. No previous reports have described awake manual reduction without the need for anesthesia, but this kind of manual reduction should be performed as soon as possible by experienced surgeons or by the right surgeons in the right places.

\section{Ethical Approval}

The device(s)/drug(s) is/are approved by the FDA or by corresponding national agency for this indication.

\section{Consent}

The authors obtained consent for the publication from the patient and family.

\section{Conflict of Interests}

The authors declare that they have no conflict of interests.

\section{References}

[1] J. W. Fielding and R. J. Hawkins, "Atlanto axial rotary fixation. (Fixed rotatory subluxation of the atlanto axial joint)," Journal of Bone and Joint Surgery A, vol. 59, no. 1, pp. 37-44, 1977.
[2] T. B. Crook and C. A. Eynon, "Traumatic atlantoaxial rotatory subluxation," Emergency Medicine Journal, vol. 22, no. 9, pp. 671-672, 2005.

[3] P. Missori, M. Miscusi, S. Paolini et al., "A C1-2 locked facet in a child with atlantoaxial rotatory fixation: case report," Journal of Neurosurgery, vol. 103, no. 6, pp. 563-566, 2005.

[4] E. Castel, J. Benazet, C. Samaha, N. Charlot, O. Morin, and G. Saillant, "Delayed closed reduction of rotatory atlantoaxial dislocation in an adult," European Spine Journal, vol. 10, no. 5, pp. 449-453, 2001.

[5] S. Fuentes, P. Bouillot, O. Palombi, A. Ducolombier, and M. Desgeorges, "Traumatic atlantoaxial rotatory dislocation with odontoid fracture: case report and review," Spine, vol. 26, no. 7, pp. 830-834, 2001.

[6] A. Goel, A. Figueiredo, S. Maheshwari, and A. Shah, "Atlantoaxial manual realignment in a patient with traumatic atlantoaxial joint disruption," Journal of Clinical Neuroscience, vol. 17, no. 5, pp. 672-673, 2010.

[7] S. W. Jeon, J. H. Jeong, S. M. Moon, and S. K. Choi, "Atlantoaxial rotatory fixation in adults patient," Journal of Korean Neurosurgical Society, vol. 45, no. 4, pp. 246-248, 2009.

[8] Y.-S. Kim, J.-K. Lee, S.-J. Moon, and S.-H. Kim, "Post-traumatic atlantoaxial rotatory fixation in an adult: c case report," Spine, vol. 32, no. 23, pp. E682-E687, 2007.

[9] J. J. Marti, J. F. Zalacain, D. E. Houry, and A. P. Isakov, "A 24-year-old woman with neck pain," American Journal of Emergency Medicine, vol. 29, no. 4, pp. 473.el-473.e2, 2011.

[10] V. K. Singh, P. K. Singh, S. K. Balakrishnan, and J. Leitao, "Traumatic bilateral atlantoaxial rotatory subluxation mimicking as torticollis in an adult female," Journal of Clinical Neuroscience, vol. 16, no. 5, pp. 721-722, 2009.

[11] R. Sinigaglia, A. Bundy, and D. A. F. Monterumici, "Traumatic atlantoaxial rotatory dislocation in adults," Chirurgia Narzadów Ruchu i Ortopedia Polska, vol. 73, no. 2, pp. 149-154, 2008.

[12] D. Stenson, "Diagnosis of acute atlanto-axial rotatory fixation in adults," Radiography, vol. 17, no. 2, pp. 165-170, 2011.

[13] M. Venkatesan, R. Bhatt, and M. L. Newey, "Traumatic atlantoaxial rotatory subluxation (TAARS) in adults: a report of two cases and literature review," Injury, vol. 43, no. 7, pp. 12121215, 2012.

[14] Y.-F. Wang, M. Mu-Huo Teng, Y.-C. Sun, W.-H. Yuan, and C.-Y. Chang, "Torticollis due to atlantoaxial rotatory fixation," Journal of Clinical Neuroscience, vol. 15, no. 3, pp. 316-318, 2008.

[15] K. R. Moore and E. H. Frank, "Traumatic atlantoaxial rotatory subluxation and dislocation," Spine, vol. 20, no. 17, pp. 19281930, 1995.

[16] M. Weißkopf, D. Naeve, M. Ruf, J. Harms, and D. Jeszenszky, "Therapeutic options and results following fixed atlantoaxial rotatory dislocations," European Spine Journal, vol. 14, no. 1, pp. 61-68, 2005. 


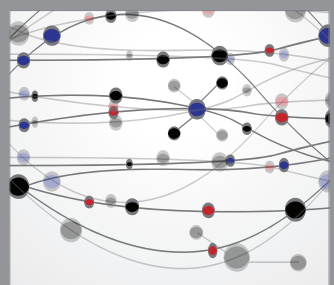

The Scientific World Journal
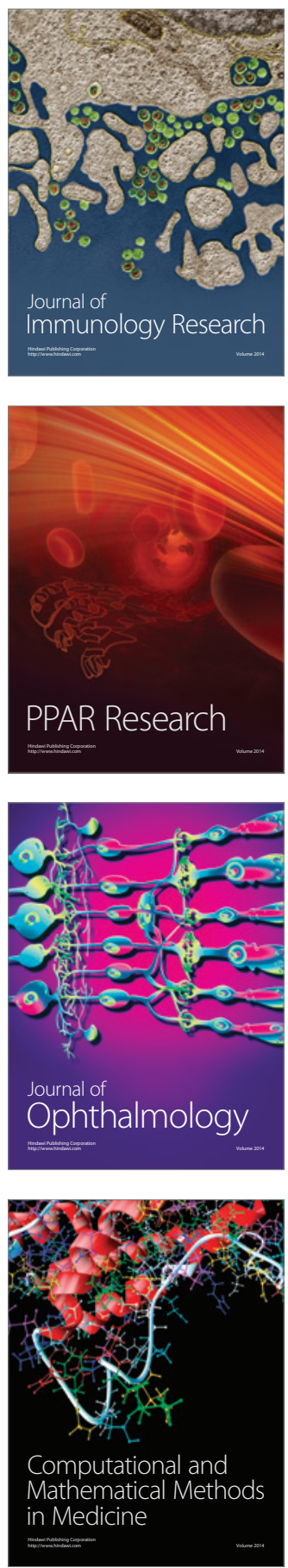

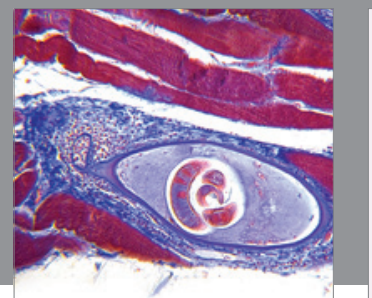

Gastroenterology

Research and Practice
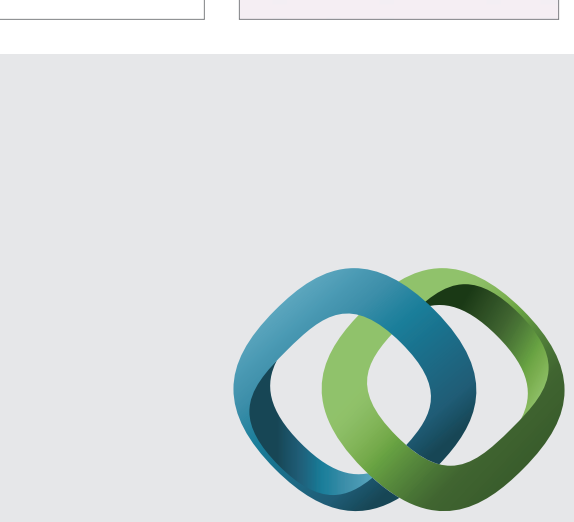

\section{Hindawi}

Submit your manuscripts at

http://www.hindawi.com
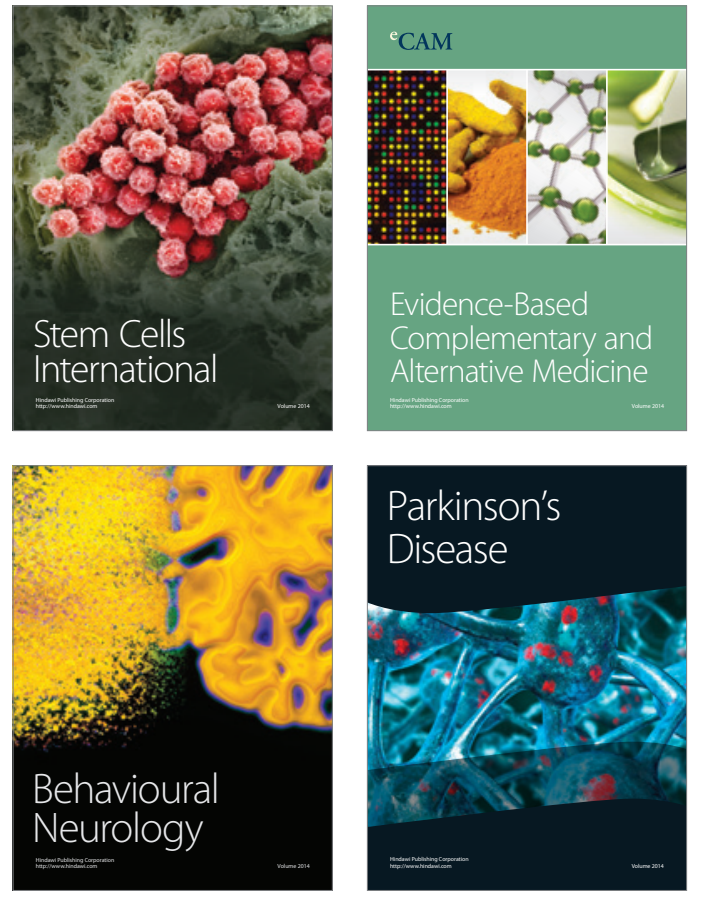
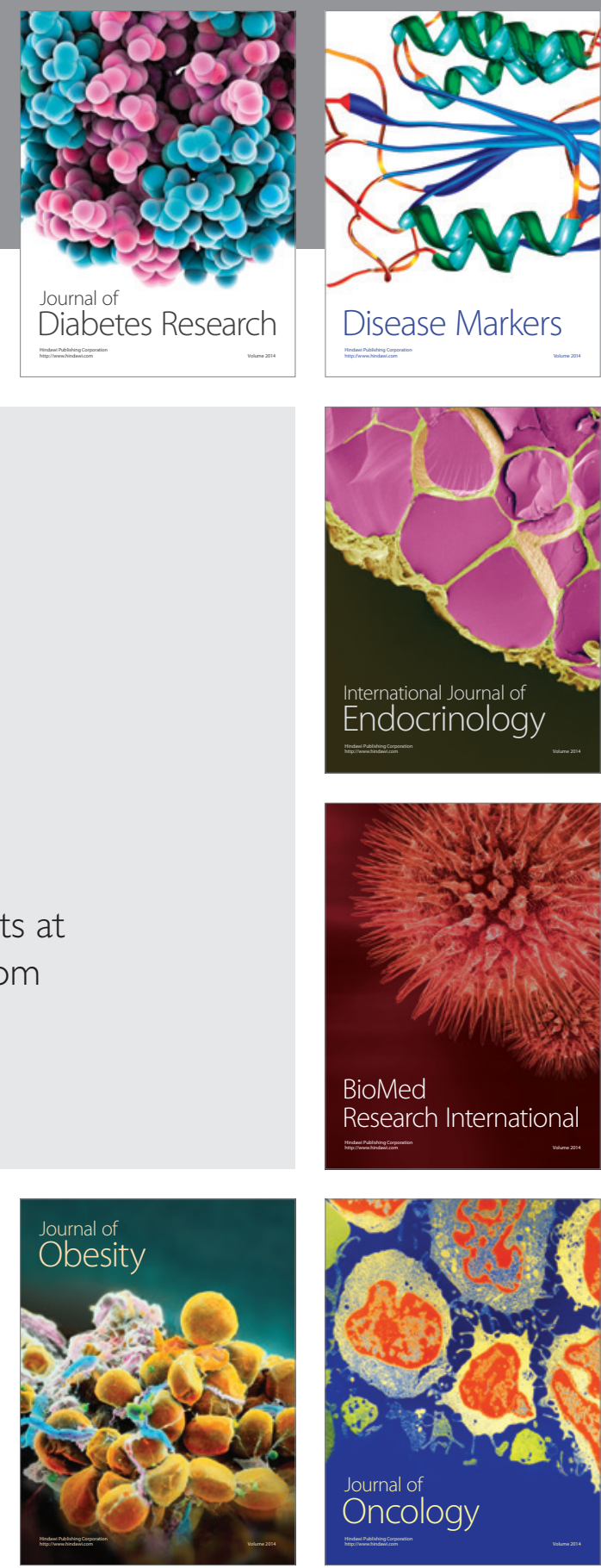

Disease Markers
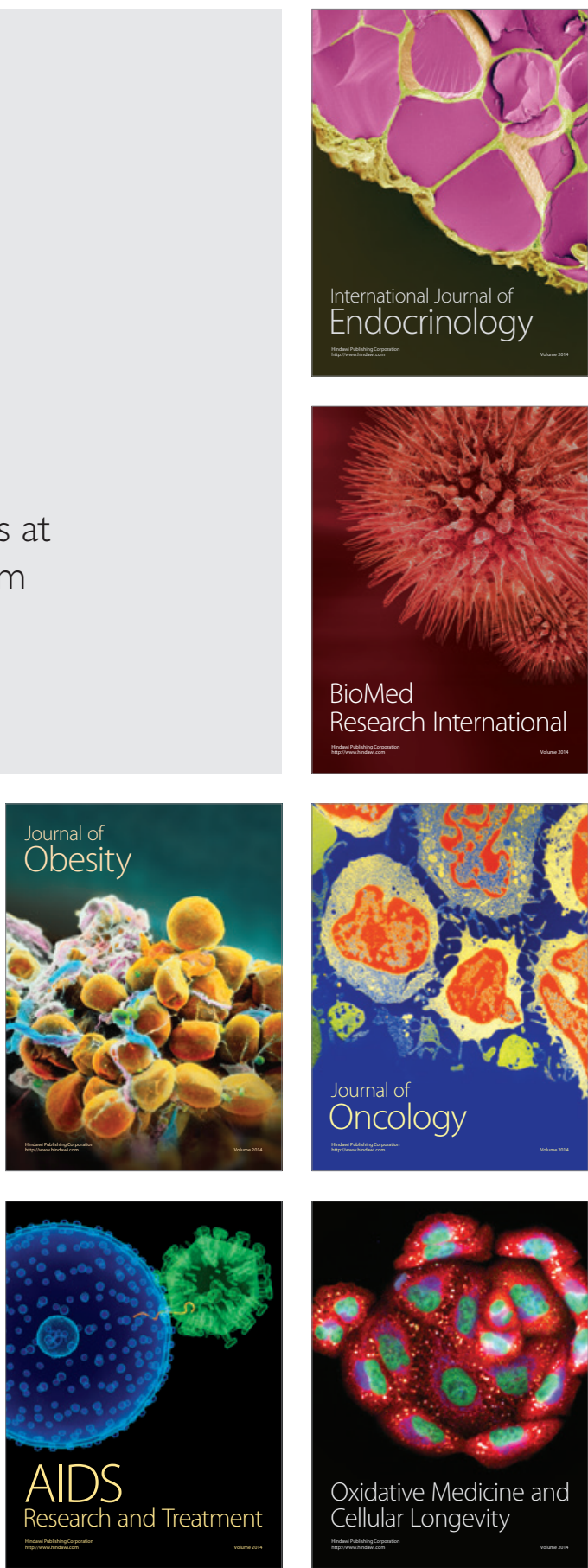